\title{
EDUKASI PENCEGAHAN PENYAKIT PARU AKIBAT PAPARAN DEBU SILIKA PADA PENGRAJIN BATU AKIK DI KOTA PADANG
}

\author{
Cimi Ilmiawati ${ }^{1)}$, Mohamad Reza ${ }^{2)}$, Russilawati ${ }^{3)}$ \\ ${ }^{1)}$ Divisi Toksikologi Lingkungan, Bagian Farmakologi, Fakultas Kedokteran, Universitas Andalas, \\ email: ilmiawati@fk.unand.ac.id \\ ${ }^{2)}$ Bagian Biologi, Fakultas Kedokteran, Universitas Andalas \\ ${ }^{3)}$ Bagian Ilmu Kesehatan Paru, Fakultas Kedokteran, Universitas Andalas
}

\begin{abstract}
ABSTRAK
Meningkatnya minat masyarakat terhadap batu akik sebagai perhiasan dalam beberapa tahun terakhir di Indonesia mendorong meningkatnya jumlah pengrajin batu akik. Pengrajin batu akik terpapar pada partikel batu yang utamanya terdiri atas silika. Tanpa proteksi diri yang sesuai, pengrajin berisiko mengalami penyakit akibat debu silika. Untuk melindungi pengrajin, diperlukan suatu program edukasi kesehatan dan keselamatan kerja. Tujuan kami adalah untuk menyebarluaskan informasi mengenai penyakit akibat debu silika dan upaya pencegahannya pada komunitas pengrajin batu akik di Kota Padang. Sebanyak dua puluh pengrajin diundang dan dinilai pengetahuan, sikap, dan perilakunya terhadap kesehatan dan keselamatan kerja menggunakan kuesioner. Bahan edukasi disampaikan dalam bahasa setempat, diikuti dengan diskusi. Pada tiap peserta juga dibagikan booklet edukasi dan masker standar. Analisis kuesioner menunjukkan bahwa sebagian besar peserta memiliki tingkat pendidikan yang rendah, tingkat pendapatan bervariasi, perokok, bekerja setiap hari, dan memiliki pengetahuan yang terbatas mengenai upaya kesehatan dan keselamatan kerja. Evaluasi lebih lanjut diperlukan untuk menilai apakah program ini berhasil memodifikasi perilaku kerja pengrajin akik.
\end{abstract}

Kata kunci: akik, edukasi, Indonesia, pengrajin, silika

\begin{abstract}
The increased public interest in the last few years towards agate as accessories in Indonesia has turned more people to grind agate as an alternative occupation. Grinders are exposed to hazardous agate particles mostly consist of silica. Without proper occupational protection, grinders are at risk of developing silica dust-associated diseases. To protect grinders, an occupational health and safety education program is needed. Our aim was to disseminate information on silica dust-associated diseases and necessary preventive measures to a community of agate grinders in Padang. Twenty participants were invited. We assessed their prior knowledge, attitude, and behavior on occupational health and safety by using a 24-items questionnaire. Educational material was presented in local language, followed by a discussion. A printed-guide on silica dust-associated diseases and a standard mask was distributed to each participant. Analysis of questionnaire responses showed that most participants were of low educational level, had variable income, were smokers, worked all weekdays, and had limited knowledge on relevant occupational health and safety practice. Further evaluation is required to assess whether this program successfully modifies the occupational behavior of the agate grinders.
\end{abstract}

Keywords: agate, education, grinder, Indonesia, silica

PENDAHULUAN

Meningkatnya minat masyarakat di

Indonesia pada umumnya, termasuk di

Sumatera Barat, terhadap batu akik sebagai koleksi ataupun perhiasan menyebabkan maraknya profesi yang terkait dengan produksi batu akik. Profesi ini membutuhkan tingkat keterampilan yang 
mudah dipelajari secara mandiri dan cukup menguntungkan dari segi ekonomi, sehingga banyak masyarakat beralih menjadi pengrajin batu akik. Pada saat program pengabdian ini dirancang, pengrajin yang terdiri atas pemotong dan pengasah batu akik dapat kita lihat di tepi jalan di berbagai lokasi strategis di Kota Padang menunggu para pengguna jasanya.

Batu akik atau agate adalah mineral yang terutama terdiri atas silika atau silikon dioksida (SiO2) yang terdapat dalam beragam warna dan corak. Silika merupakan mineral yang paling banyak di kerak bumi. Silika adalah mineral alami yang terdapat dalam bentuk kristalin dan amorf. Bentuk silika yang terbanyak adalah $\alpha$-quartz dan istilah quartz (kuarsa) sering digunakan sebagai sebutan umum untuk silika kristalin [1]. Contoh $\alpha$-quartz adalah agate (akik), chalcedony, chert, flint, jasper, dan pasir silika. Warnanya yang menarik membuat kuarsa digunakan sebagai perhiasan sejak beberapa ribu tahun silam [2].

Batu akik menjalani proses pemotongan (cutting), pengasahan (grinding) dan pemolesan (polishing) sebelum sampai pada pengguna akhir. Ketiga proses tersebut umumnya dilakukan secara tradisional dan memaparkan pengrajinnya terhadap debu silika. Proses pengasahan menghasilkan debu yang paling banyak dibanding proses lainnya [3] dan partikel debu ini $60-90 \%$ terdiri atas kristal silika [4, 5]. Partikel silika ini berukuran sangat kecil, yakni antara $2-5 \mu \mathrm{m}$, sehingga bila terhirup dapat mencapai bagian terdalam paru (alveoli) [2].

Inhalasi debu silika diketahui dapat menimbulkan sejumlah kelainan pada paru yang meliputi inflamasi akut, inflamasi kronik, fibrosis paru (silikosis), penyakit paru obstruktif kronik, dan kanker paru. Silika digolongkan sebagai karsinogen Grup 2A (probable carcinogen) oleh International Agency for Research on Cancer [2] Selain itu, silikosis juga diketahui berhubungan dengan timbulnya tuberkulosis dan penyakit autoimun [6]. Paparan kronis terhadap debu silika juga dapat menimbulkan bronkitis kronis dan emfisema tanpa ditemukannya silikosis pada pemeriksaan radiologi [7]. Efek toksik dari debu mineral silika dapat terjadi secara subklinis, di mana toksisitas terjadi dalam tubuh yang diketahui dari penanda biokimia dalam darah dan kerusakan gen, namun secara klinis subjek tidak menunjukkan gejala dan tanda. Penelitian pada hewan menunjukkan terjadinya peningkatan regulasi gen yang terlibat dalam fibrogenesis, stres oksidatif, dan degradasi matriks ekstraselular pada silikosis kronis [8].

Silikosis merupakan penyebab kematian utama pada pengasah batu akik di Thailand [9], Iran [10], Brazil, India, Hong Kong dan Cina [11]. Produksi batu akik 
bahkan dipercaya sebagai salah satu mendatang. Perhatian semua pihak, pekerjaan paling berbahaya terhadap terutama praktisi kesehatan lingkungan dan kesehatan [12, 13]. Silikosis merupakan kesehatan kerja, dalam upaya preventif jenis penyakit paru akibat debu yang paling penyakit paru akibat debu silika sangat banyak di dunia. Eliminasi silikosis secara diperlukan untuk menyelamatkan generasi menyeluruh pada tahun 2030 merupakan produktif di Kota Padang. Saat program ini target badan kesehatan dunia, WHO, dan dirancang (tahun 2015) merupakan badan pekerja internasional, ILO [14]. momentum yang tepat untuk edukasi Wabah silikosis telah dilaporkan terjadi di pengrajin batu akik melalui wadah Spanyol [15, 16], Israel [17], dan Italia [18]. pengabdian kepada masyarakat oleh Selain itu, silikosis juga membuat penderita Fakultas Kedokteran Universitas Andalas.

lebih rentan mengalami tuberkulosis sehingga kejadian siliko-tuberkulosis akan meningkat dan menjadi masalah kesehatan masyarakat baru di Indonesia. Kerusakan paru yang terjadi bersifat ireversibel sehingga upaya preventif berupa proteksi perlu dilakukan oleh semua pengrajin batu akik.

Dari observasi di lapangan, para pengrajin batu akik umumnya mengabaikan upaya perlindungan diri seperti menggunakan masker. Upaya lain yang dapat dilakukan adalah dengan bekerja menggunakan gerinda yang disiram air untuk mengurangi sebaran debu silika di udara. Debu silika tidak hanya membahayakan para pengrajin batu akik namun juga semua orang yang hidup dan bekerja di sekitar mereka. Tanpa upaya edukasi dan pencegahan yang menyeluruh, demam batu akik ini dapat berujung pada terjadinya wabah silikosis dan penyakit paru terkait lainnya dalam tahun-tahun

\section{METODE PELAKSANAAN KEGIATAN}

1. Populasi target.

Pengrajin batu akik di Kota Padang didatangi pada sentra kegiatannya di daerah Pasar Raya dan sekitar Lapangan Imam Bonjol. Mereka diminta secara sukarela untuk hadir dalam edukasi. Target peserta 20 orang.

2. Lokasi dan waktu.

Mengingat waktu kerja sangat berharga dan lokasi pengrajin yang tersebar di Kota Padang, tim pengabdian mengadakan pos penyuluhan terbuka dekat sentra pengrajin pada hari pengabdian. Pengrajin diwawancara di lokasi kerjanya kemudian diundang ke pos penyuluhan untuk mengikuti edukasi, mendapatkan masker dan booklet edukasi. Pos penyuluhan berlokasi di Lapangan Imam Bonjol dan waktu penyuluhan adalah hari Minggu.

3. Rancangan booklet edukasi.

Booklet panduan cerdas proteksi diri 
dalam pekerjaan disusun oleh tim tampak pada Tabel 1, dari 20 responden, 19 pelaksana. Booklet dilaminasi setiap (95\%) orang adalah pria dan satu orang lembar sehingga tahan lama sebagai perempuan. Usia pengrajin berkisar dari 16rujukan informasi bagi pengrajin.

4. Metode edukasi dan evaluasi. 59 tahun dengan rerata 40,4 tahun. Jadi

a. Kuesioner untuk menilai pengetahuan, sikap, dan perilaku pengrajin batu akik mengenai dampak kesehatan paparan debu silika dan upaya pencegahannya.

b. Penyuluhan menggunakan poster sebagai alat bantu visual.

c. Pembagian masker standar dan peragaan cara pakai masker yang benar.

d. Pembagian booklet edukasi.

\section{HASIL DAN PEMBAHASAN}

Kegiatan pengabdian dilaksanakan pada hari Minggu, tanggal 26 September 2015, di Lapangan Imam Bonjol Padang. Pengrajin didatangi satu-persatu, diminta kesediaannya untuk berpartisipasi, diwawancarai dan diberikan booklet edukasi. Selanjutnya, mereka diminta datang ke Lapangan Imam Bonjol yang tak jauh dari lokasi kerjanya untuk mendengarkan penyuluhan dan mendapatkan masker pelindung standar (N95). Analisis kuesioner untuk menilai pengetahuan, sikap, dan perilaku pengrajin disajikan pada Tabel 1.

\section{a. Karakteristik responden}

Profesi pengrajin batu akik pada umumnya dilakukan oleh pria. Sebagaimana profesi ini dilakoni rentang usia produktif. Separuh pengrajin berpendidikan SMA atau sederajat dan separuh lainnya berpendidikan SMP atau lebih rendah. Hal ini dapat menjadi indikator bahwa profesi pengrajin batu akik menjadi alternatif bagi pria usia produktif yang sulit mendapatkan pekerjaan di sektor formal karena terbatasnya tingkat pendidikan mereka. Dari segi penghasilan, pengrajin batu akik yang jadi partisipan sebagian besar (65\%) memiliki pendapatan bulanan 3 juta rupiah ke bawah dan sebanyak $20 \%$ mengaku dapat mencapai pendapatan di atas 5 juta rupiah. Data ini menunjukkan bahwa pendapatan seorang pengrajin batu akik sangat bervariasi dan tidak pasti. Sebagian besar pengrajin (70\%) telah menjalani profesi ini lebih dari tiga tahun. Pekerjaan mengolah batu akik bukanlah pekerjaan pertama yang dilakoni oleh $70 \%$ responden, sebelumnya mereka pernah atau masih melakukan pekerjaan lain seperti berdagang, bertani, dan profesi lainnya. Hanya 30\% responden yang menyatakan bahwa pengrajin batu akik merupakan pekerjaan pertama mereka, alihalih tidak bekerja. Profesi ini jadi pilihan karena tidak memerlukan kualifikasi khusus dan mudah dipelajari secara otodidak serta alat yang diperlukan sederhana. 
Untuk mengetahui kebiasaan yang mempengaruhi kesehatan dan menjadi faktor yang memperparah kerusakan saluran nafas akibat paparan debu batu akik, kebiasaan merokok pada responden menjadi perhatian khusus. Sebagian besar responden (75\%) adalah perokok aktif. Angka ini sesuai dengan survei WHO (2011) bahwa sekitar $70 \%$ pria di Indonesia adalah perokok (19). Lama merokok rata-rata sekitar 20 tahun dengan jumlah rokok yang dihisap per hari rata-rata 18 batang. Gambaran kebiasaan merokok pada pengrajin batu akik cukup memprihatinkan walaupun tidak mengejutkan. Penghasilan yang tidak menentu dikombinasi dengan kebiasaan merokok yang merugikan dari segi kesehatan dan finansial menjadi gambaran yang memprihatinkan pada generasi usia produktif ini.

\section{b. Karakteristik pekerjaan}

Untuk menghasilkan batu akik yang indah dan berkilau, material batu menjalani proses pemotongan agar didapatkan ukuran yang dikehendaki, pengasahan untuk didapatkan bentuk yang diinginkan, dan terakhir proses pengilapan dengan memperhalus permukaan batu. Proses pengolahan batu akik yang paling banyak menghasilkan debu adalah pemotongan dan pengasahan. Hampir semua responden melakukan ketiga proses di atas. Hanya satu atau dua orang saja yang tidak ikut memotong atau mengilapkan batu. Sebagian besar pengrajin bekerja lebih dari enam jam sehari dan bekerja setiap hari. Kondisi kerja ini akibat tidak pastinya jumlah pelanggan setiap hari. Semua pengrajin bekerja di ruangan terbuka di emper jalanan di sekitar Pasar Raya dan Lapangan Imam Bonjol Padang. Tidak hanya terpapar pada asap rokok dan debu akik, mereka juga secara rutin terpapar asap kendaraan bermotor di daerah padat lalu lintas ini.

c. Pengetahuan, sikap, dan perilaku kesehatan kerja

Pengetahuan dan sikap menjadi determinan perilaku terkait kesehatan kerja. Selain pengaruh pendidikan, faktor ekonomi menjadi penentu kepedulian terhadap kesehatan kerja. Menggunakan metode pertanyaan terbuka, hanya separuh pengrajin mengetahui bahwa pemakaian masker (40\%) dan penggunaan air pada gerinda (55\%) dapat mengurangi paparan terhadap debu batu akik. Hal ini menunjukkan rendahnya pemahaman pengrajin terhadap metode perlindungan yang sederhana ini. Cukup berbeda dengan hasil yang didapatkan menggunakan pertanyaan tertutup dengan respon tahu atau tidak tahu, $80 \%$ pengrajin mengaku tahu guna masker dan air gerinda. Semua pengrajin mengaku tahu bahwa debu batu akik berbahaya terhadap kesehatan. Namun, 95\% tidak pernah mendengar informasi tentang silikosis. Dari satu orang yang mengaku pernah mendengar tentang silikosis, ternyata 
tidak tahu apakah penyakit ini dapat hutan yang terjadi di berbagai daerah di disembuhkan atau tidak (data tidak Sumatera yang ikut mencemari udara kota disajikan). Secara umum dapat dinyatakan Padang saat penyuluhan ini dilakukan. Oleh bahwa tingkat pengetahuan pengrajin karena alasan tersebut, pentingnya mengenai kesehatan kerja sangat rendah. pemakaian masker harus disadari oleh Hal ini juga diperkuat oleh data bahwa $80 \%$ pelaku profesi ini. pengrajin tidak pernah atau jarang menggunakan masker selama bekerja. e. Penyuluhan kesehatan Hampir semua pengrajin menggunakan air pada gerinda namun lebih disebabkan oleh kemudahan melihat hasil asahan batu dan bukan didasari alasan kesehatan kerja. Sehubungan dengan risiko kesehatan inheren pada profesi ini, responden juga ditanya mengenai keinginan untuk beralih profesi. Sebanyak 25\% responden merasa nyaman dengan profesi ini dan tidak ingin beralih, $20 \%$ ingin berganti profesi dan $55 \%$ belum berpikir untuk ganti profesi.

\section{d. Gangguan kesehatan yang dialami}

Meskipun kegiatan ini hanya bersifat penyuluhan, kami juga mengumpulkan data secara umum mengenai keadaan kesehatan responden secara subjektif. Separuh responden (10 orang) pada saat wawancara mengalami keluhan saluran nafas, namun hanya empat orang yang berobat ke fasilitas kesehatan. Sebanyak tujuh orang responden juga mengalami keluhan di luar saluran nafas dan hanya satu orang yang mencari pertolongan medis untuk keluhan tersebut. Semua responden terpapar polutan udara selain debu batu akik, seperti asap rokok, asap kendaraan, serta asap pembakaran 
Tabel 1. Tabulasi karakteristik pengrajin; karakteristik pekerjaan; pengetahuan, sikap, dan perilaku pengrajin; dan gangguan kesehatan yang dialami oleh pengrajin batu akik di Pasar Raya Padang

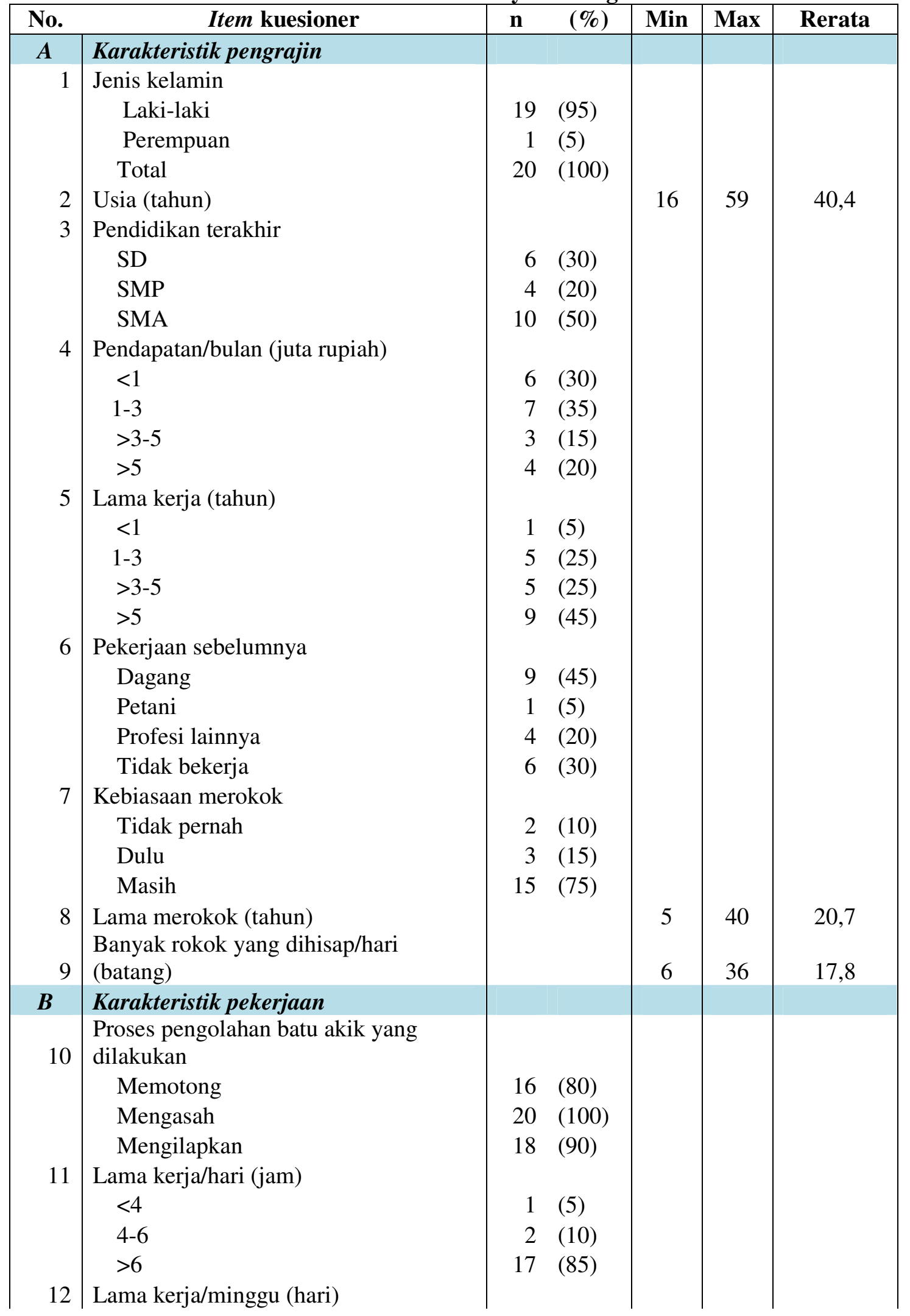




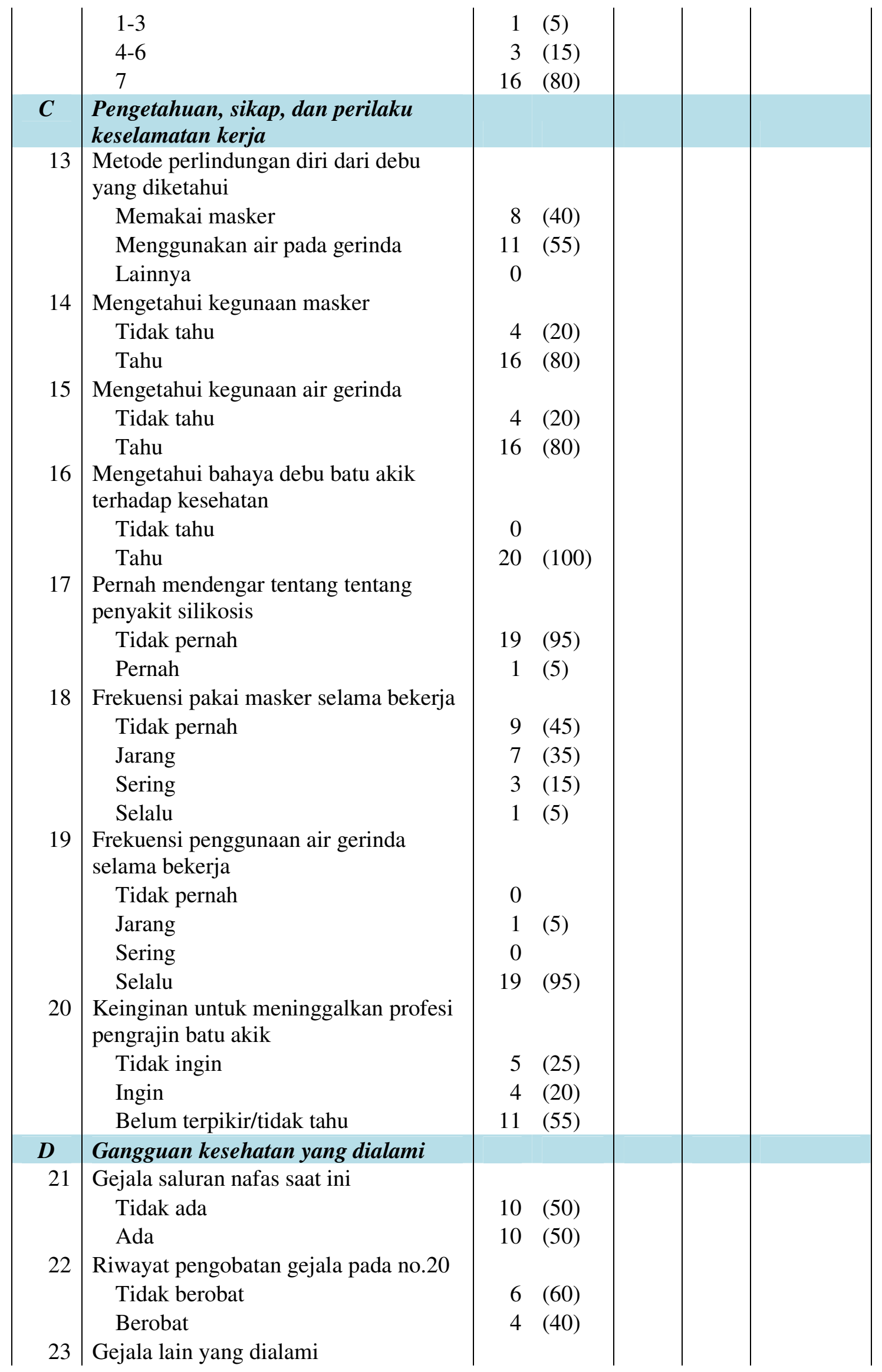




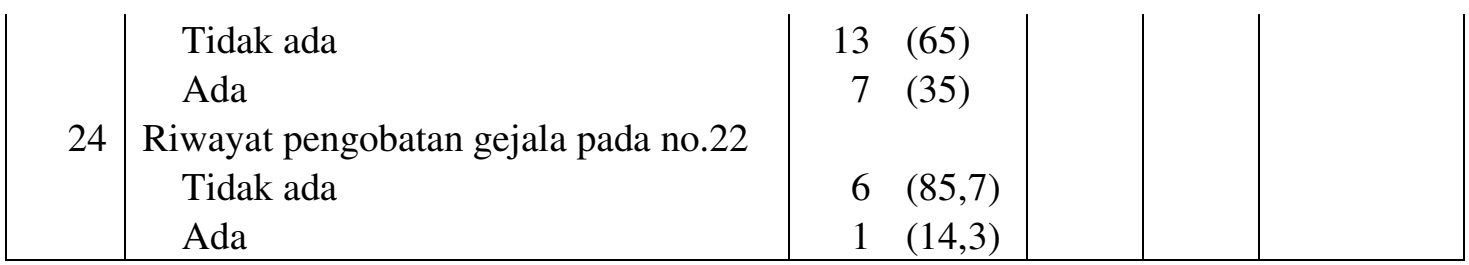

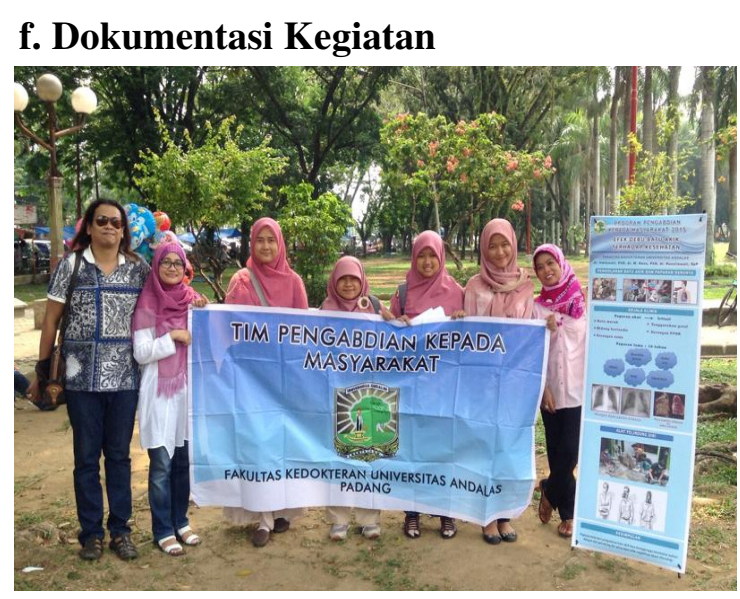

KESIMPULAN

Kegiatan yang dilakukan diharapkan dapat menjadi edukasi yang dibutuhkan oleh pengrajin dan berdampak positif terhadap perilaku kesehatan kerja mereka.

\section{SARAN}

Program edukasi berikutnya dapat menggunakan kuesioner pasca-penyuluhan untuk melihat perubahan pengetahuan dan sikap pengrajin batu akik terhadap upaya proteksi diri di lokasi kerja.

\section{UCAPAN TERIMAKASIH}

Penulis menyampaikan terimakasih kepada Crisdina Suseno, Putri Rahmadhani, Faradilla dan Metika Rahmasari atas bantuannya dalam mewawancarai pengrajin batu akik. Penulis juga menyampaikan apresiasi kepada Nila Astuti, Amd yang telah membantu persiapan logistik kegiatan ini. Pengabdian ini terlaksana dengan dukungan

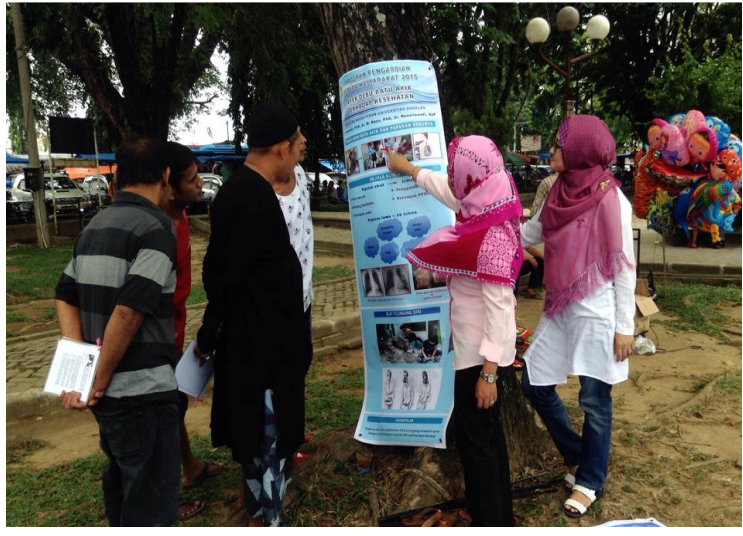

dana DIPA FK Universitas Andalas tahun 2015.

\section{REFERENSI}

1. National Institute for Occupational Safety and Health (NIOSH). 2003. Work-Related Lung Disease Surveillance Report 2002. https://www.cdc.gov/niosh/docs/2003111/. Diakses tanggal 27 Mei 2017.

2. International Agency for Research on Cancer (IARC). 1997. Monographs on the evaluation of carcinogenic risks to human Vol.68: Silica, some silicates, coal-dust and para-aramid fibrils. http://monographs.iarc.fr/ENG/Monogra phs/vol68/. Diakses tanggal 27 Mei 2017.

3. Patel J, Robbins M. 2011. The agate industry and silicosis in Khambhat, India. New Solutions. 21:117-39.

4. Sharma D, Patel T, Varshney A. 2011. A study on health effects of agate workers in Sharkarpura-Khambhat. Healthline. 2: 41-5.

5. Bhagia L, Sadhu H, Saiyed H. 2005. Prevention and control of silicosisExperience in agate industry. AsianPacific News Letter on Occupational Health and Safety. 12: 71-4.

6. Calvert GM, Rice FL, Boiano JM, 
Sheehy JW, Sanderson WT. 2003. Occupational silica exposure and risk of various diseases: an analysis using death certificates from 27 states of the United States. Occupational and Environmental Medicine. 60:120-129.

7. Hnizdo E, Vallyathan V. 2003. Chronic obstructive pulmonary disease due to occupational exposure to silica dust: A review of epidemiological and pathological evidence. Occupational and Environmental Medicine. 60:237-243.

8. Langley RJ, Mishra NC, PenaPhilippides JC, Rice BJ, Seagrave JC, Singh SP et al. 2011. Fibrogenic and redox-related but not proinflammatory genes are upregulated in Lewis rat model of chronic silicosis. Journal of Toxicology and Environmental Health A. 74:1261-1279.

9. Yingratanasuk T, Seixas N, Barnhart S, Brodkin D. 2002. Respiratory health and silica exposure of stone carvers in Thailand. International Journal of Occupational and Environmental Health. 8:301-308.

10. Rafeemanesh E, Majdi MR, Ehteshamfar SM, Fahoul MJ, Sadeghian Z. 2014. Respiratory diseases in agate grinding workers in Iran. International Journal of Occupational and Environmental Medicine. 5:130-136.

11. Leung CC, Yu IT, Chen W. 2012. Silicosis. Lancet. 179: 2008-2018.

12. Kulkarni GK. 2007. Prevention and control of silicosis: A national challenge. Indian Journal of Occupational and Environmental Medicine. 11: 95-96.

13. Patel J. Indian gems and jewellery industry. http://www.lac.org.hk/en/node/8.

Diakses tanggal 22 Maret 2015.

14. Igor A, Gerry JM. 2007. ILO/WHO global program for the elimination of silicosis. GOHNET Newsletter Issue 12. http://www.who.int/occupational_health/ publications/newsletter/gohnet12e.pdf.

Diakses tanggal 22 Maret 2015.

15. Garcia VC, Sanchez Gomez J, Romero Morillo J. 2011. Silicosis in quartz conglomerate workers. Archivos de Bronconeumología. 47: 6.

16. Pérez-Alonso A, Córdoba-Doña JA, Millares-Lorenzo JL et al. 2014. Outbreak of silicosis in Spanish quartz conglomerate workers. International Journal of Occupational and Environmental Health. 20: 26-32.

17. Kramer MR, Blanc PD, Fireman E et al. 2012. Artificial stone silicosis disease among artificial stone workers. Chest. 142: 419-24.

18. Bartoli D, Banchii B, Di Benedetti F et al. 2012. Silicosis in employees in the processing of kitchen, bar and shop countertops made from quartz resin composite. Provisional results of the environmental and health survey conducted within the territory of USL 11 of Empoli in Tuscany among employees in the processing of quartz resin composite materials and review of the literature. Italian Journal of Occupational and Environmental Hygiene. 3:6.

19. WHO. Global Adult Tobacco Survey: Indonesia 2011. http://www.who.int/tobacco/surveillance /survey/gats/indonesia_report.pdf.

Diakses tanggal 11 November 2015. 